\title{
DAMPAK PERSEPSI PESERTA DIDIK TENTANG KETERAMPILAN MENGAJAR GURU DAN FASILITAS BELAJAR TERHADAP MINAT BELAJAR PESERTA DIDIK
}

\author{
Risma Dhini Eka Pratiwi, Kanaria Herwati \\ Universitas Indraprasta PGRI \\ Jakarta
}

\begin{abstract}
ABSTRAK
Penelitian ini bertujuan untuk mengetahui seberapa besar pengaruh persepsi siswa tentang keterampilan mengajar guru dan fasilitas pembelajaran terhadap minat peserta didik. Metode penelitian yang digunakan dalam penelitian ini adalah metode deskriptif kuantitatif dan sampel yang digunakan sebanyak 200 responden. Pengambilan sampel menggunakan random sampling. Analisis data yang digunakan adalah dengan menggunakan teknik regresi berganda. Hasil penelitian berupa persamaan regresi linier berganda yang diperoleh berdasarkan perhitungan yaitu $\mathrm{Y}=38,630+0,234 \mathrm{X} 1+0,613 \mathrm{X} 2$ dengan F hitung $=12,089$ sedangkan nilai Ftabel untuk taraf nyata $\alpha=5 \%, n=200$ adalah 3,04 maka Fhitung> Ftabel ditemukan pengaruh persepsi peserta didik tentang keterampilan mengajar guru dan fasilitas belajar terhadap minat belajar siswa pada SMK Negeri di Kota Depok.
\end{abstract}

Kata kunci: persepsi keterampilan mengajar guru, fasilitas belajar, minat belajar

\section{THE IMPACT OF STUDENT PERCEPTION ON TEACHER TEACHING SKILLS AND LEARNING FACILITIES ON STUDENTS 'LEARNING INTERESTS}

\begin{abstract}
This study Has a goal to determine how much influence the students' perception about the teaching skills of teachers and learning facilities to the interests of learners. The research method used in this research is descriptive quantitative method and the sample used is 200 respondents. The sampling used by random sampling. The data analysis used is by using multiple regression techniques. Result for research form of equation regression linear multiple which is obtained based on the calculation that is $Y=38.630$ $+0.234 X 1+0.613$ X2 with Fcount $=12.089$ while the value of Ftable for real level $\alpha=5 \%, n=200$ is 3.04 then Fcount $>$ Ftable be found influence perceptions about the skills of learners teaching teachers and learning facilities to students' learning interests at Public Vocational High Schools in Depok City.

Keywords: perception skills of teaching, the facilities of learning, interest in learning
\end{abstract}

\section{PRELIMINARY}

Education in Indonesia is currently of low quality; this can be seen from the low level of student interest in learning. Interest in learning is an essential thing in education for students before carrying out learning activities. Because learners' interest can determine the outcome of a learner's obtained learners, good or bad, these results can be influenced by the interests of learners. If students' interest in learning is lacking, students will have difficulty and feel burdened to carry out learning activities.

So, interest in learning is included in the main factor for students to start the learning process. Because if there is no intention in students to learn, learning will not go well. Students 
will find it difficult to accept the knowledge and knowledge appropriately provided and get less than optimal learning outcomes.

Currently, many students still have an interest in learning at the school low. The low interest in learning of students may also be caused by several factors, including teacher teaching skills and learning facilities.

\section{Interest in Learning}

Djali (in Sukarno, 2018) states that "Interest can be expressed through a statement which shows that students prefer one thing over another, it can be manifested through participation in an activity". Students who have an interest in learning will make it easier for them to carry out learning activities.

\section{Students' perceptions of teacher teaching skills}

In the journal Atika Prama Deswita (2013), according to Slameto (2010: 102), "Perception is the process of entering messages or information into the human brain." Meanwhile, according to Thoha (2009: 141-142), "Perception is a cognitive process in which everyone understands information about their environment." So, by having sense organs and using them when observing something, humans can predict an event they see.

Based on some of the opinions above, the researcher concluded that skill is talent and skill that a person has in carrying out an activity. Something that is carried out can be resolved or can be well accepted. Similar to a teacher, a teacher must have teaching skills when carrying out the learning process. The importance of creativity to support Deliver learning material to the participant learners

\section{Learning Facilities}

Djamarah (in Rahman, 2015) revealed that the facility support learning students at the school. Learning facilities are divided into two parts consisting of teaching facilities and infrastructure.

Based on some of the opinions above, the researcher can conclude that the facility is a piece of equipment provided to simplify and ease an activity. In the scope of education, learning facilities are also very much needed to facilitate students' carrying out the learning process and make it easier for teachers to transfer knowledge to students. Having adequate learning facilities is also likely to increase students' interest in learning because all activities are facilitated to be easy, efficient, and maximum.

Yonitasari (2014) explained that there are five indicators of learning facility variables that are studied in this study, namely: (1) school buildings, (2) classrooms, (3) school libraries, (4) learning aids and instructional media, (5) textbooks.

With the facilities, all work or what will be carried out will run smoothly and smoothly. Likewise, when learning, learning also requires adequate facilities to make it easier for students to carry out the learning process and make it easier for teachers to convey knowledge and knowledge easily during the learning process. Students become understood and understand and easily grasp the understanding provided by the teacher. With adequate facilities, students can participate in learning activities maximally.

\section{RESEARCH METHODS}

The method used in this research is a descriptive Analytical, quantitative approach through regression. Object research was the students of class X Subject BKP, TKJ, BDP, OTKP, PSY, and AKL at Vocational High School 3 in Depok sed balustrades samples used were 200. Data collection techniques using documentation study and questionnaires.

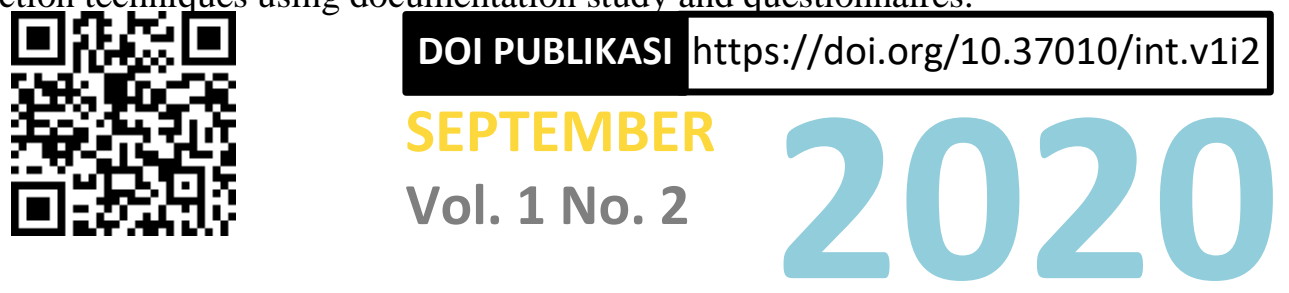




\author{
Risma Dhini Eka Pratiwi, Kanaria Herwati \\ Universitas Indraprasta PGRI
}

\title{
RESULTS AND DISCUSSION
}

The relationship functional between $\mathrm{X} 1$ and $\mathrm{X} 2$ are together with $\mathrm{Y}$ can be presented in equation regression linear multiple, which is obtained based on the calculation that is $\mathrm{Y}=38.630$ $+0.234 \times 1+0.613 \times 2$. Due to the value of the coefficient of regression $b 1$ and $b 2$ is positive, namely 0.234 and 0.163 then it can be said that the influence of independent variable X1 (perception participant students about the skills of teaching the teachers) and independent variable $\mathrm{X} 2$ (facilities study) are joint to variable tied $\mathrm{Y}$ is low.

And to test that there is the influence of the positive independent variable $\mathrm{X} 1$ (perception participant students about the skills of teaching the teachers) and independent variable $\mathrm{X} 2$ (facilities study) are joint to variable tied Y required to test the significance of the coefficient of the regression. The regression coefficient requirement is significant if Fcount $>$ Ftable. Because the value of $F=12.089$, while the amount of $F$ table for the whole level $\alpha=5 \%, n=200$ is 3.04 , then the $\mathrm{F}$ count $>\mathrm{F}$ table, which means that the regression coefficient is significant or, in other words, a considerable influence variable 1 free Perceptions participants learners about Teacher teaching skills (X1) and Learning Facilities (X2) together on the dependent variable Learning Interest (Y).

From the calculation results obtained multiple correlation coefficient between independent variables X1 (Perception participant students about the skills of teaching the teachers) and X2 (Facility Learning) with the dependent variable Y (Interests Learning) is equal to 0.334 . According to the existing criteria indicate that the relationship bo ga these variables is low. While $\mathrm{r} 2$ is 0.112 and the coefficient determination of $11.2 \%$ suggests that the participant students' perception about the skills teach teachers and facilities Learning mem provide contributions towards Interests learning is $11.2 \%$, the remaining $88.8 \%$ due to the influence of other factors.

\section{CONCLUSION}

There is a simultaneous effect between the participant students' perception about the skills of teaching teachers and facilities learned to ar the interest in the School of Secondary Vocational in Depok. Teachers' teaching skills and learning facilities are two variables that determine the level of student interest in learning so that if the teacher's teaching skills and learning facilities are adequate, the student. If in learning, specifically when attending lessons at Depok State Vocational School, it will be good too.

\section{BIBLIOGRAPHY}

Amaliah, D. (2012). Evaluasi Pembelajaran. Jakarta: Unindra Press.

Cynthia, L. C., Tristono, Martono, dan Mintasih, I. (2016). Pengaruh Fasilitas Belajar dan Motivasi Belajar terhadap Prestasi Belajar Mata Pelajaran Ekonomi Siswa Kelas XI IIS di SMA Negeri 5 Surakarta Tahun Ajaran 2015/2016. Jurnal Pendidikan Bisnis Dan Ekonomi. Vol.1 No.1, 1-20.

Deswita, A. P. (2013). Pengaruh Persepsi Siswa Tentang Gaya Mengajar Guru dan Minat Belajar Siswa terhadap Hasil Belajar Akuntansi pada Program Keahlian Akuntansi Siswa Kelas $\mathrm{X}$ di SMKN 1 Sawahlunto. Journal of Economic and Economic Education. Vol.2 No.1, $1-10$.

Elsam. (2014, November 26). UU Nomor 20 Tahun 2003 Tentang Sistem Pendidikan Nasional. Diakses pada tanggal 25 Oktober 2019. https://referensi.elsam.or.id

DOI UNTUK ARTIKEL INI

https://doi.org/10.37010/int.v1i2.99
Scan barcode untuk mengunjungi OJS 
Firmansyah, D. (2015). Pengaruh Strategi Pembelajaran Dan Minat Belajar terhadap Hasil Belajar Matematika. Jurnal Pendidikan Unsika. Vol.3 No.1, 34-44.

Hidayat, S. (2017). Pengembangan Guru Profesional. Bandung: PT Remaja Rosdakarya.

Kopertis3. (2010, Juli). Peraturan Pemerintahan Republik Indonesia Nomor 19 Tahun 2005 tentang Standar Nasional Pendidikan. www.kopertis3.or.id

Kurniawan, R. dan Yuniarto, B. (2018). Analisis regresi dasar dan penerapannya dengan $R$. Depok: Prenadamedia Group.

Lestari, S., Amaliah, D., Interdiana, A., dan Amega, N. (2018). Strategi belajar dan pembelajaran. Jakarta: Unindra Press.

Rahman, M. F. (2015). Pengaruh Dukungan Orang Tua dan Fasilitas Belajar di Sekolah terhadap Prestasi Belajar Ekonomi melalui Motivasi Belajar Siswa Kelas VIII SMP Negeri 2 Ungaran. ProsidingSemiar Nasional Pendidikan Ekonomi \& Bisnis. 1-7.

Sa'ud, U.S. (2011). Pengembangan Profesi Guru. Bandung: Alfabeta.

Satmoko, A. A. (2013). Pengaruh Persepsi Siswa Mengenai Keterampilan Mengajar Guru Dan Motivasi Berprestasi terhadap Prestasi Belajar Ekonomi Siswa Kelas XI IPS SMA Negeri 3 Purworejo. Program Studi Pendidikan Ekonomi. Fakultas Ekonomi. Semarang: Universitas Negeri Semarang.

Sekaran, U. dan Bougie, R. (2017). Metode Penelitian untuk Bisnis. Jakarta: Salemba Empat.

Semiawan. (2000). Belajar dan Pemberdayaan Dalam Taraf Pendidikan Usia Dini (Pendidikan Prasekolah dan Sekolah Dasar). Jakarta: PT Gramedia Widia Sarana.

Setyawan, E. 2016. Kemampuan Belajar Siswa Kelas VIII pada Mata Pelajaran Ilmu Pengetahuan Sosial Ditinjau dari Minat Belajar Siswa dan Persepsi Siswa Tentang Keterampilan Mengajar Guru di SMP Islam Kedung Kabupaten Jepara Tahun Pelajaran 2016/2017. Program Studi Pendidikan Akuntansi. Fakultas Keguruan dan Ilmu Pendidikan. Surakarta: Universitas Muhammadiyah Surakarta.

Siagian, R. E. F. (2015). Pengaruh Minat Dan Kebiasaan Belajar Siswa terhadap Prestasi Belajar Matematika. Jurnal ilmiah pendidikan MIPA. Vol.2 No.2, 122-131.

Slameto. (2010). Belajar dan Faktor-Faktor yang Mempengaruhinnya. Jakarta: PT Rineka Cipta. Sugiyono. (2017). Metode Penelitian Kuantitatif, Kualitatif, dan R\&D. Bandung: PT Alfabeta.

Sukarno, A. Z. dan Prih, H. (2018). Pengaruh Penggunaan Gadget, Minat Belajar dan Kecerdasan Emosional terhadap Hasil Belajar Siswa Kelas XI IIS pada Mata Pelajaran Ekonomi di SMAN 1 Kepanjen. Jurnal Pendidikan Ekonomi. Vol.11 No.1, 09-19.

Supardi. (2017). Aplikasi Statistika dalam Penelitian. Jakarta: Change Publication.

Syafril. (2019). Statistik Pendidikan. Jakarta: Prenadamedia Group.

Walgito, B. (2010). Pengantar Psikologi Umum. Yogyakarta: Andi.

Yasmin, Z. dan Santoso, B. (2019). Fasilitas Belajar dan Metode Mengajar Guru sebagai Faktor yang Mempengaruhi Hasil Belajar Peserta Didik. Jurnal Pendidikan Manajemen Perkantoran. Vol.4 No.1, 260-266.

Yonitasari, D. dan Rediana, S. (2014). Pengaruh Cara Belajar, Lingkungan Keluarga, dan Fasilitas Belajar terhadap Prestasi Belajar Ekonomi Akuntansi Siswa Kelas XI IPS SMA Negeri 4 Magelang Tahun Ajaran 2013/2014. Economic Education Analysis Journal. Vol.3 No.2, 241-248. 